\title{
An Approach for Fast Statistical Data Extraction from Biomedical Objects
}

\author{
Aleksandrs Sisojevs ${ }^{1}$, Rihards Starinskis ${ }^{2}$ \\ ${ }^{1}$ Engineering Research Institute "Ventspils International Radio Astronomy Centre”, Ventspils University College, \\ ${ }^{2}$ Riga Stradins University
}

\begin{abstract}
The statistical data of biomedical object is very important input information for medical diagnostics or/and anatomical pathology research. The approach for this data extraction is photo survey of biomedicine object and next image processing, based on image segmentation. For image segmentation methods of pattern recognition can be used. In the present research, the authors implement different methods for extracting the statistical data from images. The experimental results show the efficiency of the selected methods and proposed modification.
\end{abstract}

Keywords - Aortic valve, pattern recognition, segmentation, statistics.

\section{INTRODUCTION}

The use of image processing methods for medical diagnostics is an important scientific problem. The present paper is continuation of research that is described in [1]. Calcific aortic valve disease (CAVD) is an abnormal process that affects aortic valve leaflets characterised by progressive calcium deposition in the middle layer of the valve. More than $26 \%$ of adults at the age of 65 and $48 \%$ at the age of 85 have CAVD. The pathologic process is very complex and includes activation of inflammatory signalling pathways, including the complement system, tumour necrosis factor $\alpha(\mathrm{TNF} \alpha), \mathrm{C}$-reactive protein, interleukin 1, tumour growth factor $\beta$ (TGF $\beta$ ) [2].

The therapeutics methods, excluding surgery, are very limited and have a little effect. The surgery methods include conventional aortic valve replacement (CAVR) and transcatheter aortic valve replacement (TAVR) for patients with a high operative risk [3], [6]. Transthoracic echocardiography is a routine medical technique and at the same time is a key technique that is used to confirm CAVD. For more detailed aortic valve visualisation, multislice computed tomography (CT) and magnetic resonance imaging (MRI) are used [5]. The quantity and location of calcification are important parameters to predict mortality, morbidity and complications after TAVR [4].

After CAVR it is possible to use numbers of techniques to research the aortic valve. In the present research, our aim was to score the calcification area in the post-CAVR aortic valve.

There is growing interest in the detection and quantification of AVC. Detection and accurate quantification of AVC may be important for diagnostics, prognostics, and research applications [3]. For example, AVC is strongly associated with paravalvular regurgitation after Transcatheter aortic valve replacement [5]. Our aim was to score the calcification area in the postoperative aortic valve.

\section{IMPLEMENTED METHODS}

In order to solve the task of image segmentation, methods of object recognition (classification) were used in the present research. The same approach was used in [1].

In this paper, the objects of classification were sets of image pixels described in the RGB colour system.

$$
A_{i}=\left(\begin{array}{lll}
R_{i} & G_{i} & B_{i}
\end{array}\right)
$$

Two methods of object recognition were used: "Template Matching" and " $k$ Nearest-Neighbours" method (or "FixHodges method" [10], [11]). In those studies, the modification of " $k$ Nearest-Neighbours" method was proposed. The method "Template Matching" [12], [13] for our task is described in [1].

\section{A. Method "kNearest-Neighbours"}

Method " $k$ Nearest-Neighbours" or Fix-Hodges method [14], [15] is also a classification method, which in this paper was used for the purpose of image segmentation. The geometric interpretation of the method as used in the present research is illustrated in Fig. 1.

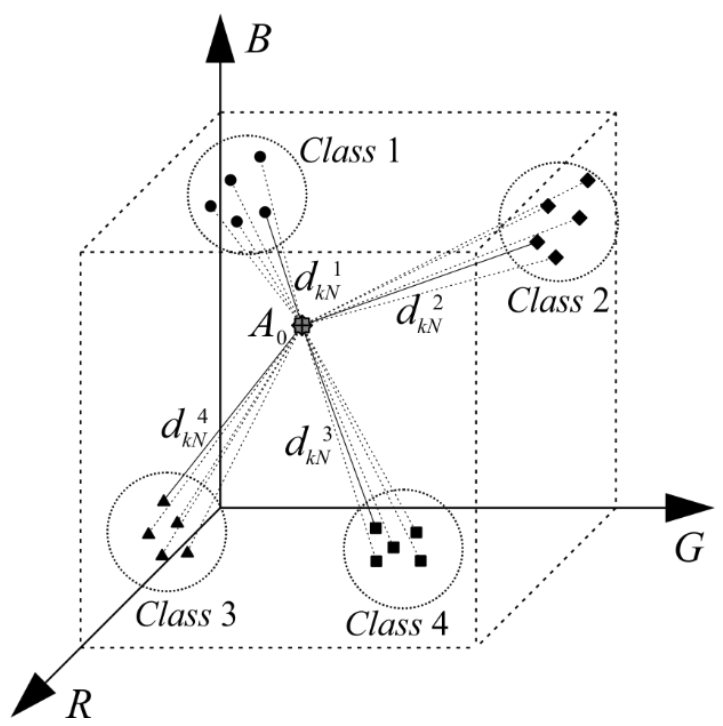

Fig. 1. The geometric interpretation of " $k$ Nearest-Neighbours" method.

When using this method, a consecutive analysis is conducted for each image pixel, where the class affiliation for the pixel is unknown. The method consists of the following steps:

In the beginning, the distances (in RGB space) between the examined pixel and each object in the learning set are calculated: 


$$
d_{i}^{p}=\left|A_{0}-A_{i}^{p}\right|
$$

where:

$A_{0}$ - the examined object;

$A_{i}^{p}-$ object $i$ of class $p$;

$p$ - class number;

$i-$ number of the object in class $p$.

Afterwards, in each class the minimal distance to the examined object is calculated, the search for the examined object's nearest neighbour from the class objects:

$$
d_{k N}^{p}=\min \left(d_{1}^{p}, d_{2}^{p}, \ldots\right)
$$

The decision about the affiliation of the examined object (pixel) $A_{0}$ to the specific class is made by finding the minimal distance to the nearest neighbour in each class, i.e. the object belongs to class $p$, if one of its object's distance to the examined object is minimal:

$$
\text { if }\left(d_{k N}^{p}=\min \left(d_{k N}^{0}, d_{k N}^{1}, \ldots\right)\right) \text { then } A_{0} \in \text { Classp. }
$$

The " $k$ Nearest-Neighbours" method implements piecewise linear partition of the attribute space, which allows using this method as the approximation of the non-linear partition of attribute space.

\section{B. Used Distance Metrics}

As seen from (5), the methods of classification are based on using distances between objects in 3D space of RGB colour system. Different metrics [17] can be used to calculate these distances. In the present research, Euclidean distance [17] was used. Let there be two points $A_{1}$ and $A_{2}$ in RGB colour space. The coordinates of the points are calculated using (5). In this case, the distance between these two points when using Euclidean metric can be calculated as follows:

$$
d_{\text {Eucl }}=\sqrt{\left(R_{1}-R_{2}\right)^{2}+\left(G_{1}-G_{2}\right)^{2}+\left(B_{1}-B_{2}\right)^{2}} .
$$

\section{PROPOSED MODIFICATION}

To decrease the time segmentation, this paper proposed modification of the $k$-nearest neighbours algorithm. The main idea of the proposed modification is reduction of objects in the class $p$. The set of known objects class $p$ is subdivided into several subclasses. Then, in each of the subclasses a template is computed. A set of received templates of subclasses creates a new class for use in the k-nearest neighbours algorithm.

The implementation of the proposed modification consists of the following steps: assigning additional parameter $t$ to objects of the test class and the subsequent division into subsets. Described parts can be implemented consistently throughout the following steps.

Step 1: in the test class two objects with the maximum distance between them are selected. Let us describe these points as $p_{s}$ and $p_{f}$.
Step 2: Translation of all objects of test class so that point $p_{s}$ coincides with the origin (the point $(0,0,0))$. The translation matrix can be described as follows:

$$
[T]=\left[\begin{array}{rrrr}
1 & 0 & 0 & 0 \\
0 & 1 & 0 & 0 \\
0 & 0 & 1 & 0 \\
-p_{s, R} & -p_{s, G} & -p_{s, B} & 1
\end{array}\right] .
$$

Figure 2 illustrates this case.

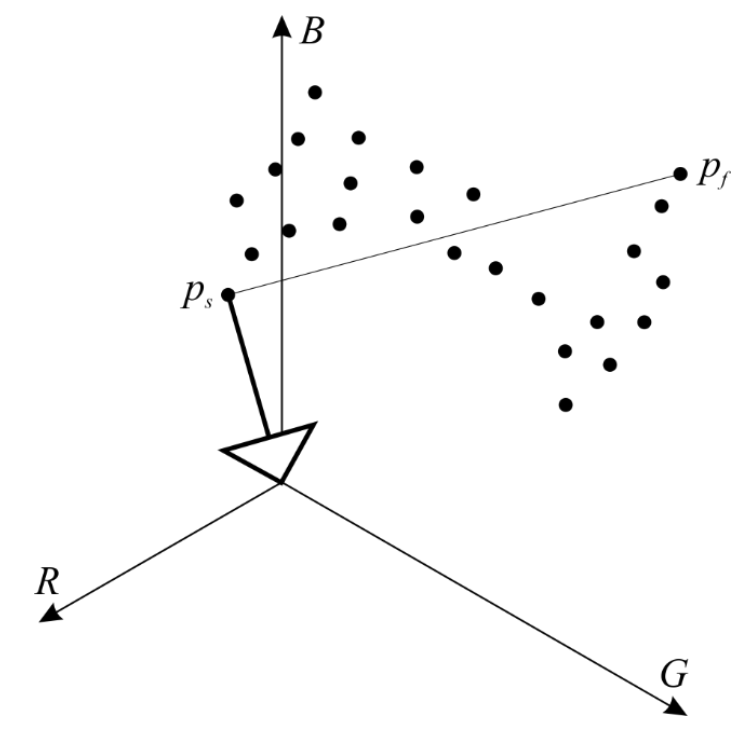

Fig. 2. Translation of class $p$.

Step 3: the rotation of the test object class so that the line segment $p_{s}-p_{f}$ coincides with one of the coordinate axes. In the experimental part of this paper, the rotation axis is applied to coordinate $\mathrm{Ob}$. In this case, the complex rotation by two simple rotations is implemented: the first rotation is around the $\mathrm{Or}$ axis, and the second rotation is around the $O b$ axis.

The rotation matrix around the $O r$ axis is as follows:

$$
\left[R_{R}\right]=\left[\begin{array}{cccc}
1 & 0 & 0 & 0 \\
0 & \cos (\alpha) & \sin (\alpha) & 0 \\
0 & -\sin (\alpha) & \cos (\alpha) & 0 \\
0 & 0 & 0 & 1
\end{array}\right] .
$$

where:

$$
\cos (\alpha)=\frac{p_{f, B}}{\sqrt{p_{f, G}^{2}+p_{f, B}^{2}}} .
$$

and

$$
\sin (\alpha)=\frac{p_{s, G}}{\sqrt{p_{f, G}^{2}+p_{f, B}^{2}}} .
$$

Taking to consideration that the rotation about the $O_{g}$ axis takes a negative direction, the rotation matrix is as follows: 
$2015 / 16$

$$
\left[R_{G}\right]=\left[\begin{array}{cccc}
\cos (\beta) & 0 & \sin (\beta) & 0 \\
0 & 1 & 0 & 0 \\
-\sin (\beta) & 0 & \cos (\beta) & 0 \\
0 & 0 & 0 & 1
\end{array}\right]
$$

where:

$$
\cos (\beta)=\frac{\sqrt{p_{f, G}^{2}+p_{f, B}^{2}}}{\sqrt{p_{f, R}^{2}+p_{f, G}^{2}+p_{f, B}^{2}}}
$$

and

$$
\sin (\beta)=\frac{p_{f, R}}{\sqrt{p_{f, R}^{2}+p_{f, G}^{2}+p_{f, B}^{2}}} .
$$

Figure 3 illustrates the rotation of class $p$.

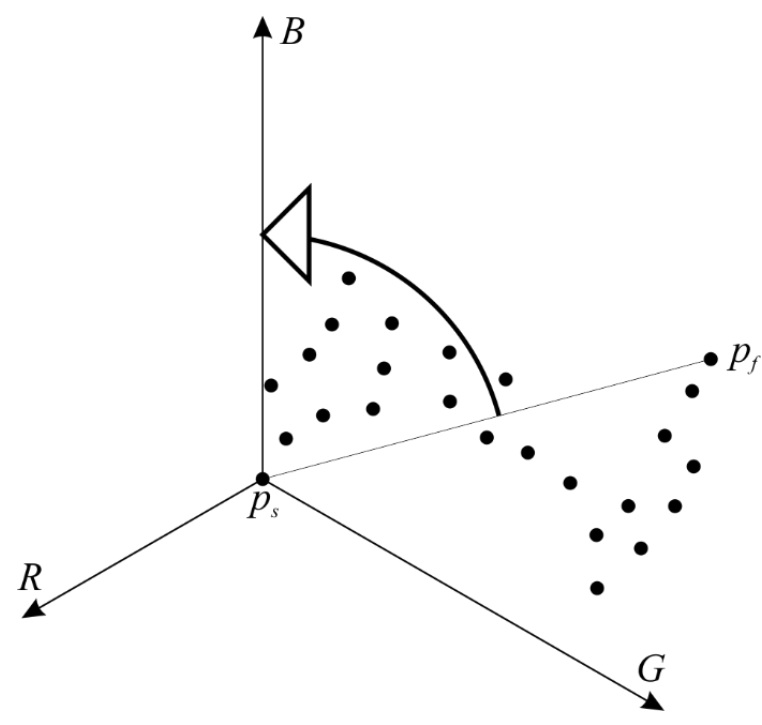

Fig. 3. Rotations of class $p$.

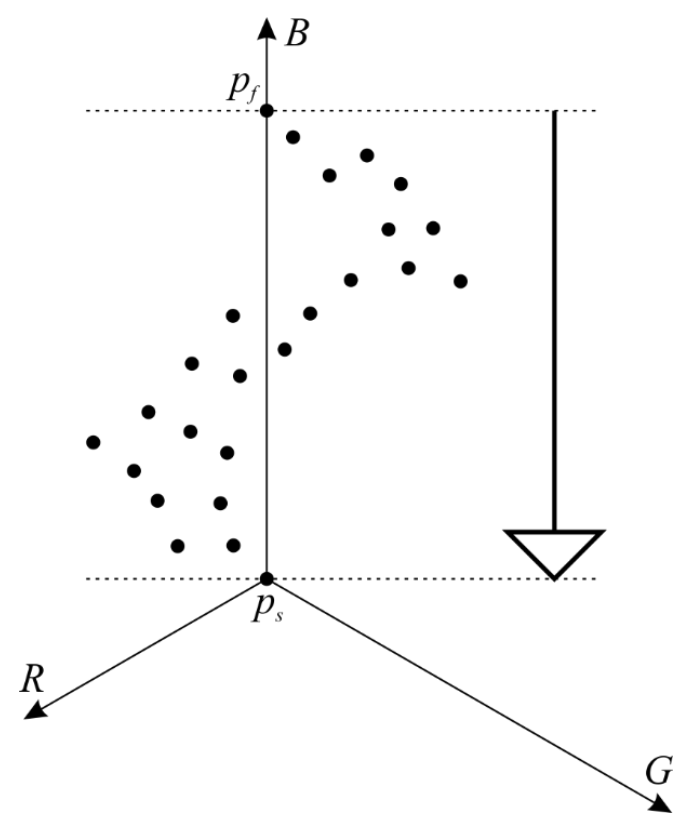

Step 4: The scaling of the test class by $O b$ axis. Scaling matrix in this case takes the form:

$$
\left[S_{B}\right]=\left[\begin{array}{cccc}
1 & 0 & 0 & 0 \\
0 & 1 & 0 & 0 \\
0 & 0 & 1 / p_{f, B} & 0 \\
0 & 0 & 0 & 1
\end{array}\right] .
$$

Figure 4 illustrates this case.

The scaling result is normalization of test class along $\mathrm{Ob}$ axes, coordinate $B$ values in the objects of class are in the range $[0.0 ; 10]$. This case is shown in Fig. 5.

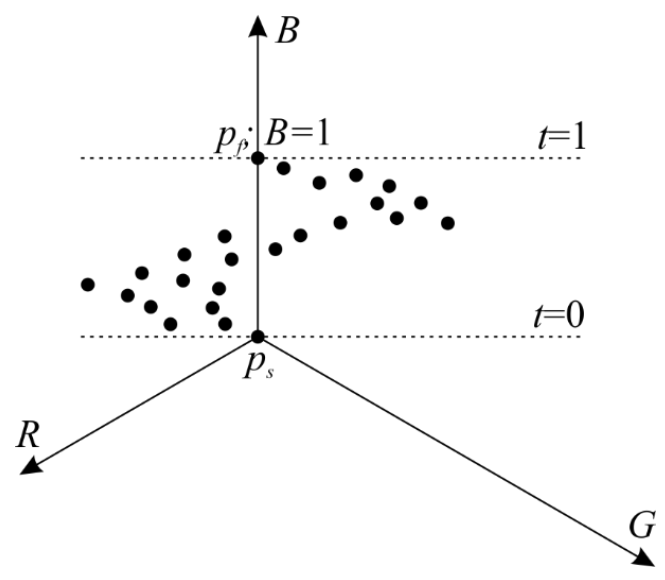

Fig. 5. Class $p$ after normalization.

Thus, it can assign the value of additional parameter $t$ for the test object class using condition:

$$
t_{i}=p_{i, B}
$$

Step 5: Splitting a set of objects on a subset of the test class as shown in Fig. 6.

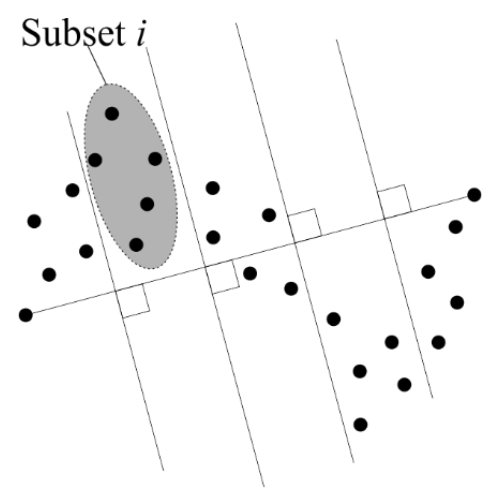

Fig. 6. Class $p$ splitting by subsets.

For class $p$ splitting into subsets, the value of parameter $t$ is used:

$$
N=\left\lfloor\frac{t_{i}}{S}\right\rfloor .
$$

Fig. 4. Scaling of class $p$. 
where:

$N$ - number of the subsets which include the $i$-th object from class $p$;

$t_{i}$ - value of parameter t of $i$-th object in class $p$;

$S$ - number of subsets for which test class $p$ is spitted.

Step 6: Calculating template values in each subset as shown in Fig. 7.

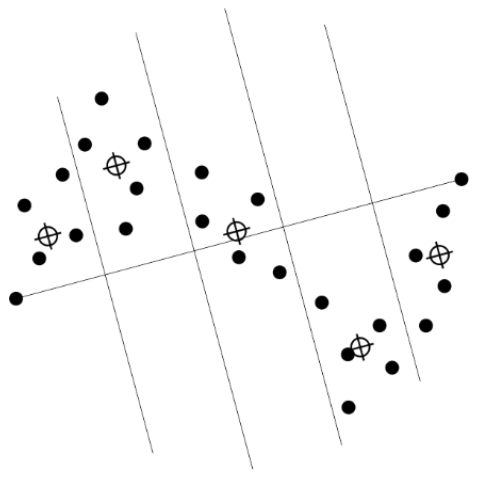

Fig. 7. Templates of subsets.

Thus, new objects were obtained to create a class for use in the method " $k$ Nearest-Neighbours".

\section{EXPERIMENTAL RESULTS}

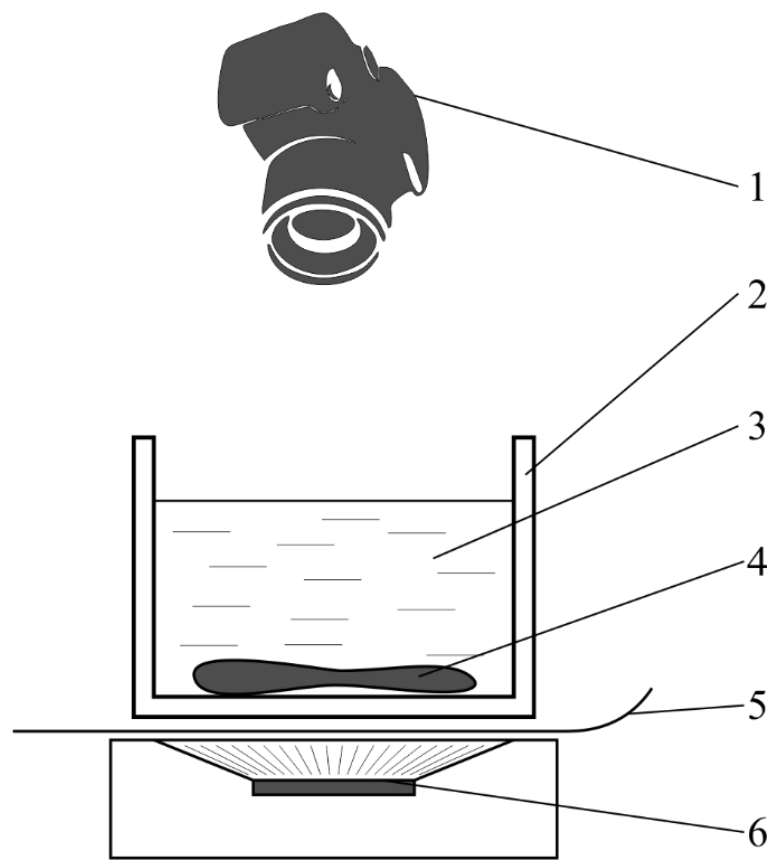

Fig. 8. Photo shooting scheme.

In [1], the input data were photo images of biopsy object. On the images of [1] there is lack - glare on biopsy objects. This problem was solved in [1] only in part.

In the present research, biopsy objects - aortic valve obtained from surgical operations - were available. These objects were kindly provided for research by Dr. med., asoc. prof. Pēteris Stradinšs (Heart Surgery Centre of the Latvian Cardiology Centre at Pauls Stradins Clinical University Hospital).
Thus, the first task of the experimental part of research was the task of photographic shooting.

\section{A. Photo Shooting of Biopsy Objects}

In the experimental part of the research, biomedical object photo shoot was applied across the light. Fig. 6 shows the scheme of photo shooting. Fig. 8 demonstrates the shooting scheme that consists of:

1. photo camera;

2. glass bowl;

3. saline solution $(\mathrm{NaCl})$;

4. biological object (aortic valve);

5. paper;

6. LED light source.

The result of photo shooting was 6 photo images of heart valve.

\section{B. Photo Image Segmentation and Statistic Data Extraction}

For experiments 6 biomedical objects were accessible. The first step was the photo survey of objects. For statistical data extraction, the following input data were used:

- 6 aortic heart valve photographs;

- 6 template segmentation images.

The input images are shown in Table I.

TABLE I

INPUT IMAGES FOR SEGMENTATION
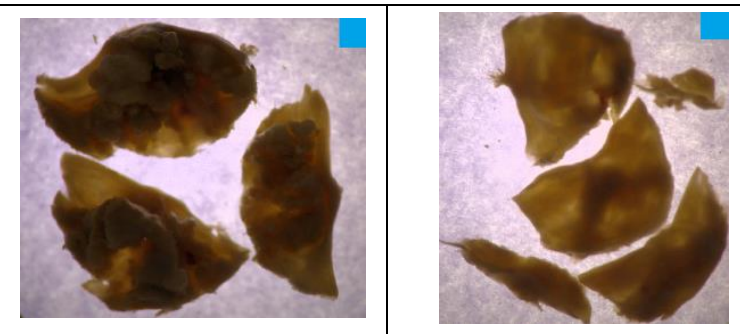

1)

2)
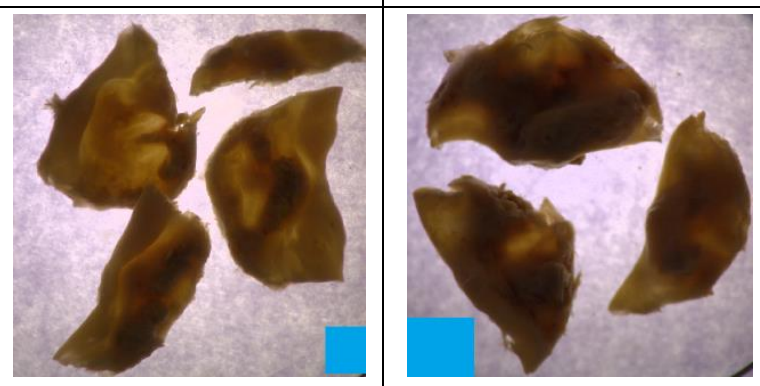

3)

4)
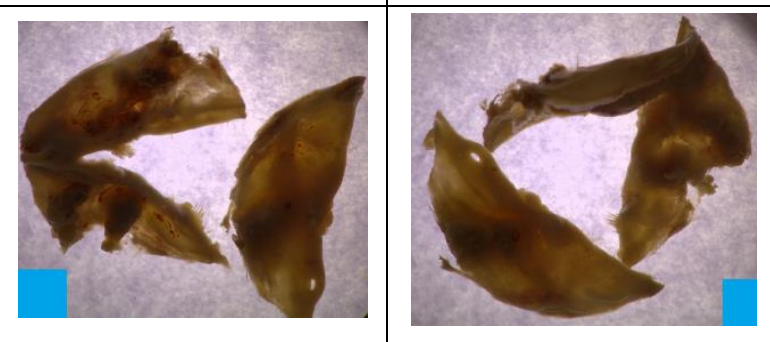

6) 
$2015 / 16$

In make the methods "Template Matching" and " $k$ NearestNeighbours" work properly, it is necessary to use images of the start values (segment map). An example of such a segment map for the input images is shown in Fig. 9.

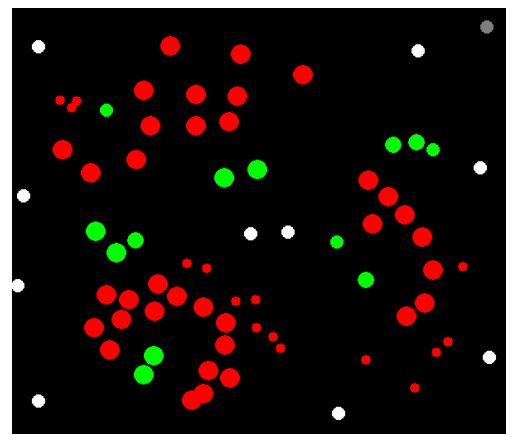

Fig. 9. The example of start segment images.

The testing was performed at two stages. The first stage was the segmentation of 6 input images based on 6 segment maps (each input image has its own respective segment map). Each image was processed with three different segmentation methods: "Template Matching" method, " $k$ NearestNeighbour" method and modified " $k$ Nearest-Neighbour" method.

The second stage of testing implied calculating the number of pixels in the segmented regions of interest as well as the percentile correlation of these regions. In practice, two classes of segments were examined - the pathological tissue and the macroscopically unchanged tissue [1].

The first experiment was the segmentation of input images based on the segment map using the method "Template Matching" with Euclidean metric. The statistical results are shown in Table II.

TABLE II

Statistical Data OF SEGMENTATION USING THE “TEMPLATE MATCHING” METHOD

\begin{tabular}{|c|c|c|c|c|c|}
\hline Object & \multicolumn{2}{|c|}{ Sample } & \multicolumn{3}{c|}{ Segmentation } \\
\hline No. & $\begin{array}{c}1 \text { class, } \\
\%\end{array}$ & $\begin{array}{c}2 \text { class, } \\
\%\end{array}$ & $\begin{array}{c}1 \text { class, } \\
\%\end{array}$ & $\begin{array}{c}2 \text { class, } \\
\%\end{array}$ & $\begin{array}{c}\text { difference, } \\
\%\end{array}$ \\
\hline 1 & 80.011 & 19.989 & 69.591 & 30.409 & -10.420 \\
\hline 2 & 57.705 & 42.295 & 48.213 & 51.787 & -9.492 \\
\hline 3 & 76.684 & 23.316 & 66.451 & 33.549 & -10.233 \\
\hline 4 & 75.746 & 24.254 & 62.367 & 37.633 & -13.379 \\
\hline 5 & 64.586 & 35.414 & 64.888 & 35.112 & 0.302 \\
\hline 6 & 70.308 & 29.692 & 53.93 & 46.070 & -16.378 \\
\hline
\end{tabular}

As seen from Table II, the use of "Template Matching" method and Euclidean metric gives a not-so-good result in terms of precision (less than $5 \%$ difference) only in 1 out of 6 objects $(16.7 \%)$.

The second experiment performed on the images was the segmentation of input images based on the segment map using the unmodified method " $k$ Nearest-Neighbours" with Euclidean metric. The input data were the same as in the first experiment. The statistical results for the third experiment are shown in Table III.
TABLE III

STATISTICAL DATA OF SEGMENTATION USING UNMODIFIED “ $K$ NEAREST-NEIGHBOURS” METHOD

\begin{tabular}{|l|c|c|c|c|c|}
\hline Object & \multicolumn{2}{|c|}{ Sample } & \multicolumn{3}{c|}{ Segmentation } \\
\hline No. & $\begin{array}{c}1 \text { class, } \\
\%\end{array}$ & $\begin{array}{c}2 \text { class, } \\
\%\end{array}$ & $\begin{array}{c}1 \text { class, } \\
\%\end{array}$ & $\begin{array}{c}2 \text { class, } \\
\%\end{array}$ & $\begin{array}{c}\text { difference, } \\
\%\end{array}$ \\
\hline 1 & 80.011 & 19.989 & 76.931 & 23.069 & -3.080 \\
\hline 2 & 57.705 & 42.295 & 58.467 & 41.533 & 0.762 \\
\hline 3 & 76.684 & 23.316 & 84.142 & 15.858 & 7.458 \\
\hline 4 & 75.746 & 24.254 & 74.371 & 25.629 & -1.375 \\
\hline 5 & 64.586 & 35.414 & 62.625 & 37.375 & -1.961 \\
\hline 6 & 70.308 & 29.692 & 70.191 & 29.809 & -0.117 \\
\hline
\end{tabular}

As seen from Table III, the use of " $k$ Nearest-Neighbours" method and Euclidean metric gives a good result in terms of precision (less than $5 \%$ difference) in 5 out of 6 objects $(83.3 \%)$.

The third experiment performed on the images was the segmentation of input images based on the segment map using the modified method " $k$ Nearest-Neighbours" with Euclidean metric. The input data were the same as in the first two experiments. The statistical results for the third experiment are shown in Table IV.

TABLE IV

Statistical Data of Segmentation Using the Modified “ $K$ NeARestNEIGHBOURS" METHOD

\begin{tabular}{|c|l|l|l|l|l|}
\hline Object & \multicolumn{2}{|c|}{ Sample } & \multicolumn{3}{c|}{ Segmentation } \\
\hline No. & $\begin{array}{l}1 \text { class, } \\
\%\end{array}$ & $\begin{array}{l}2 \text { class, } \\
\%\end{array}$ & $\begin{array}{l}1 \text { class, } \\
\%\end{array}$ & $\begin{array}{l}2 \text { class, } \\
\%\end{array}$ & $\begin{array}{l}\text { difference, } \\
\%\end{array}$ \\
\hline 1 & 80.011 & 19.989 & 77.211 & $22 ., 789$ & -2.800 \\
\hline 2 & 57.705 & 42.295 & 55.547 & 44.453 & -2.158 \\
\hline 3 & 76.684 & 23.316 & 74.643 & 25.357 & -2.041 \\
\hline 4 & 75.746 & 24.254 & 75.02 & 24.980 & -0.726 \\
\hline 5 & 64.586 & 35.414 & 63.554 & 36.446 & -1.032 \\
\hline 6 & 70.308 & 29.692 & 69.319 & 30.681 & -0.989 \\
\hline
\end{tabular}

As seen from Table IV, the use of modified " $k$ NearestNeighbours" method gives the best result in terms of precision (less than $5 \%$ difference) in 6 out of 6 objects $(83.3 \%$ ).

In Table $\mathrm{V}$, the time of segmentation in experiments is given.

As seen from Table $\mathrm{V}$, the use of modified " $k$ NearestNeighbours" method gives a good result in terms of segmentation time.

TABLE V

TIME OF SEGMENTATION IN EXPERIMENTS

\begin{tabular}{|c|c|c|c|}
\hline Object & Methods & & \\
\hline No. & $\begin{array}{l}\text { "Template } \\
\text { Matching", sec }\end{array}$ & $\begin{array}{l}\text { Unmodified " } k \\
\text { Nearest-Neighbours", } \\
\text { min:sec }\end{array}$ & $\begin{array}{l}\text { Modified " } k \\
\text { Nearest- } \\
\text { Neighbours", sec }\end{array}$ \\
\hline 1 & 0.06 & 03:00.8 & 0.3 \\
\hline 2 & 0.05 & 01:21.0 & 0.31 \\
\hline 3 & 0.06 & 01:38.8 & 0.3 \\
\hline 4 & 0.07 & 01:58.9 & 0.33 \\
\hline 5 & 0.07 & 01:45.9 & 0.34 \\
\hline 6 & 0.06 & $01: 48.2$ & 0.32 \\
\hline
\end{tabular}




\section{RESUlTS AND CONCLUSION}

Some pattern recognition methods ("Template Matching" method and method of " $k$ Nearest-Neighbours") were implemented in the present research in order to solve the task of image semi-automatic segmentation.

After a series of experiments it was concluded that:

- the method of " $k$ Nearest-Neighbours" provided a more precise result than the "Template matching" method;

- the modification of " $k$ Nearest-Neighbours" methods gave a better result by segmentation time.

It could also be noted that the method of " $k$ NearestNeighbours" required more time for full segmentation (up to 3 minutes) when compared to "Template Matching" method (up to 0.1 seconds).

The segmentation time by modified " $k$ Nearest-Neighbours" methods was approximately equivalent to "Template Matching" method (up to 0.6 seconds).

A manual method of segmentation (by analogy [1]) was also applied in order to obtain the sample results for experiments.

\section{ACKNOWLEDGEMENT}

The research was supported by the National Research Programme "The next generation of information and communication technologies" (NexIT).

\section{REFERENCES}

[1] A. Sisojevs, K. Boločko, R. Starinskis, "An Approach for Statistical Data Extraction from Photo Images of Pathological Biopsy Objects," RTU Journal, Technologies of Computer Control, vol. 15, 2014, pp. 5-13. http://dx.doi.org/10.7250/tcc.2014.001

[2] Freeman RV, Otto CM, Chapter 76. "Aortic Valve Disease.” In: Fuster V, Walsh RA, Harrington RA. eds. Hurst's The Heart, 13e. New York, NY: McGraw-Hill; 2011.

[3] Smith CR, Leon MB, Mack MJ, et al., for the PARTNER Trial Investigators. "Transcatheter versus surgical aortic-valve replacement in high-risk patients." $N$ Engl J Med, 2011, 364, pp. 2187-98. http://dx.doi.org/10.1056/NEJMoa1103510

[4] Omar K. Khalique, MD, Rebecca T. Hahn, MD, Hemal Gada, MD et a "Quantity and Location of Aortic Valve Complex Calcification Predicts Severity and Location of Paravalvular Regurgitation and Frequency of Post-Dilation After Balloon-Expandable Transcatheter Aortic Valve Replacement," JACC Cardiovasc Interv., vol. 7, no. 8, 2014. http://dx.doi.org/10.1016/i.jcin.2014.03.007

[5] P.Stradiņš, M.Kalējs, I. Brečš Aortas vārstuḷa stenoze - diagnoze un ārstēšana Latvijas Ārsts, 05/04/2013.
[6] 2014 AHA/ACC Guideline for the Management of Patients With Valvular Heart Disease A Report of the American College of Cardiolog.

[7] J. D. Miller, R.M. Weiss, D.D. Heistad, "Calcific Aortic Valve Stenosis: Methods, Models, and Mechanisms," Circ. Res. http://dx.doi.org/10.1161/CIRCRESAHA.110.234138

[8] M. Misfeld, H.-H Sievers, "Heart valve macro- and microstructure," University of Luebeck, Clinic of Cardiac and Thoracic Surgery, RatzeburgerAllee 160, 23538 Luebeck, Germany.

[9] Guidelines on the management of valvular heart disease (version 2012) The Joint Task Force on the Management of Valvular Heart Disease of the European Society of Cardiology (ESC) and the European Association for Cardio-Thoracic Surgery (EACTS).

[10] E. Fix, J.L. Hodges, Discriminatory analysis, nonparametric discrimination: Consistency properties. Technical Report 4. - USAF School of Aviation Medicine, Randolph Field, Texas, 1951.

[11] E. Fix, J.L. Hodges, Discriminatory analysis-nonparametric discrimination: small sample performance. Technical Report, - USAF, TX, 1952. (Reprinted as pp. 280-322 of Agrawala, 1977.)

[12] R. O. Duda, P.E. Hart, D.G. Stork, Pattern Classification, 2nd Edition. Wiley-Interscience, 2000.

[13] N.J. Nilsson, The Mathematical Foundations of Learning Machines. San Francisco: Morgan Kaufmann, 1990.

[14] E.A. Patrick, Fundamentals of pattern recognition. Prentice-Hall, 1972.

[15] T.M. Mitchell, Machine Learning, McGraw-Hill Science, 1997.

[16] R. Starinskis, V. Groma, A. Sisojevs, "Aortas vārstuḷa stenozes morfoloǵiskā un datorizētā attēlu analīze," RSU XIX Morfologisisko zinātṇu konferences referātu tezes. Rīga: Rīgas Stradina universitāte, lpp. 38.-39., 2014.

[17] D. Randall Wilson, T. R. "Martinez, Improved Heterogeneous Distance Functions." Journal of Artificial Intelligence Research, vol. 6, pp. 1-34, 1997. http://dx.doi.org/10.1613/jair.346

[18] R.Euler, J.Sadek, "The $\pi$ s Go Full Circle." Mathematics Magazine, vol. 72, no. 1, pp. 59-63, 1999.

[19] R. Jin, S. Wang, Y. Zhou, "Regularized Distance Metric Learning: Theory and Algorithm," Advances in Neural Information Processing Systems 22, pp. $862-870,2009$.

Aleksandrs Sisojevs was born in 1980. He is a Senior Researcher at the Engineering Research Institute "Ventspils International Radio Astronomy Centre" of Ventspils University College and a Lecturer at Riga Technical University, Faculty of Computer Science and Information Technology, Department of Image Processing and Computer Graphics.

He received Bc. sc .ing. (2001) and Dipl. ing (2003) from Riga Technical University, Mg. sc. comp. (2006) from the University of Latvia and Dr. sc. ing. (IT) in 2011 from Riga Technical University.

His research interests include computer graphics, geometrical modelling and computer vision.

E-mails: alexiv@inbox.lv

Rihards Starinskis was born in 1992. He is a Student at Riga Stradins University, Faculty of Medicine.

His research interests include cardiology, morphology and anatomical pathology.

E-mail: rihards9211@gmail.com

TABLE VI

SEGMENTATION IMAGES IN EXPERIMENTS

\begin{tabular}{|l|c|c|c|c|}
\hline No. & Sample segmentation & "Template Matching" method & $\begin{array}{c}\text { Method of "k Nearest- } \\
\text { Neighbours" }\end{array}$ & $\begin{array}{c}\text { Proposed modification of "k } \\
\text { Nearest-Neighbours" method }\end{array}$ \\
\hline & & &
\end{tabular}




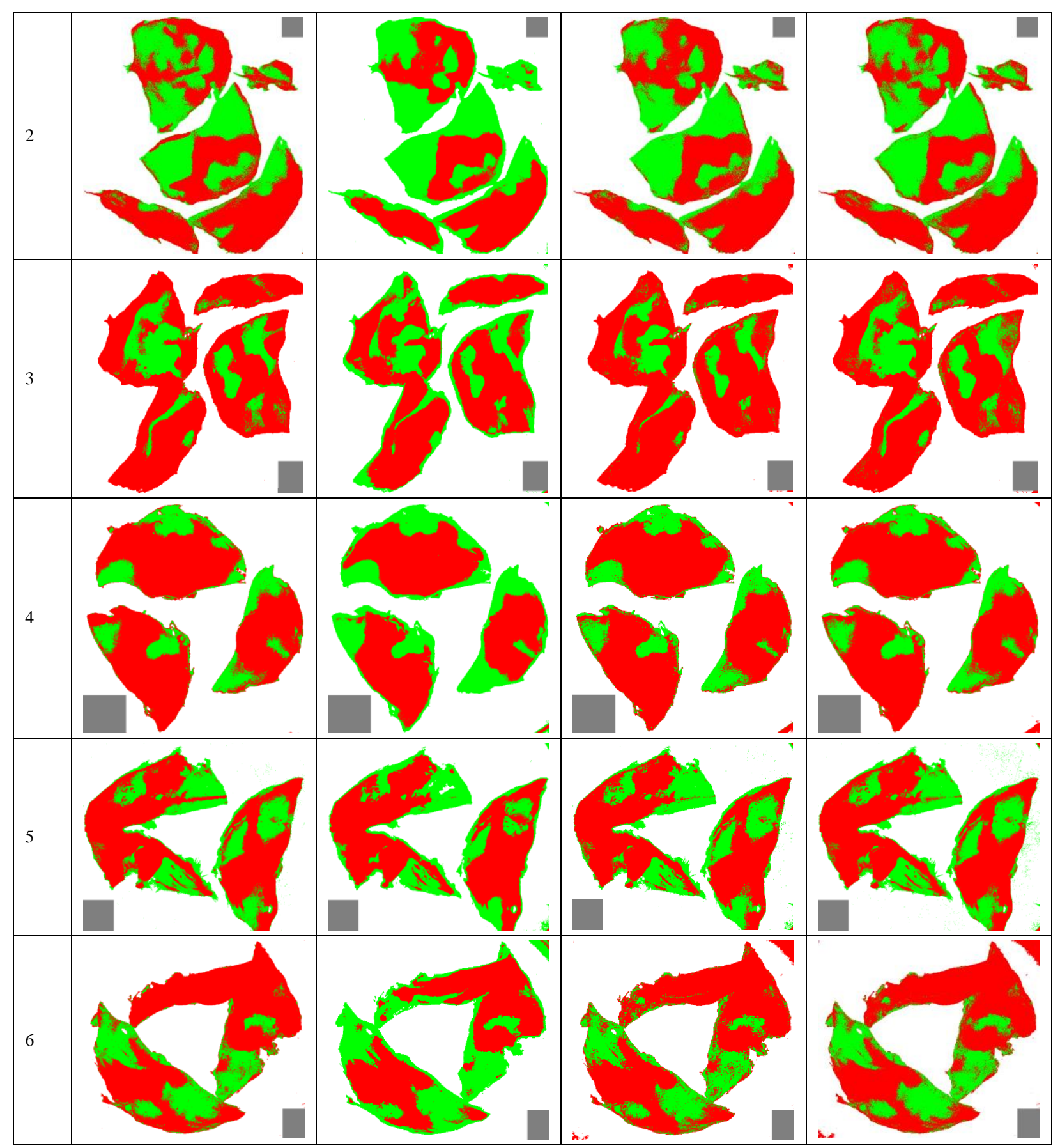

Sisojevs Aleksandrs, Starinskis Rihards. Biomedicīnas objektu ātras statistisko datu ieguves pieeja

Biomedicīnas objektu statistiskie dati ir svarīga informācija medicīnas diagnostikā un biomedicīnas pētījumos. Tādā veidā no medicīnas prakses viedokḷa datu iegūšanas uzdevums ir aktuāls (piemēram, aortas vārstuḷa slimību diagnostikā un/vai patologanatomiskos pētījumos). Šajā darbā tiek apskatīts statistisko datu iegūšanas uzdevums no sirds vārstuḷu fotogrāfiskiem attēliem, precīzāk, aortas vārstuḷu (Valva aortae) attēliem, kas uzņemti pēc kiirurǵiskām operācijām.

Šĩ uzdevuma risināšana tiek sadalīta trīs posmos. Pirmais posms ir eksistējošo biomedicīnas objektu foto filmēšana, izmantojot caurejošu gaismu. Otrais posms ir fotoattēlu, kuri tika iegūti pirmajā posmā, segmentācija. Šī uzdevuma risināšanai dotajā darbā tika lietotas divas tēlu atpazišanas metodes: "salīdzināšana ar etalonu" un "k tuvāko kaimiņu". Kā arī esošā darba ietvaros tika piedāvāta "k tuvāko kaimiņu" metodes modifikācija, kura ḷauj ievērojami paātrināt segmentāciju. Trešais posms ir interesējošo segmentu izmēru aprēḳināšana, lietojot nākamo procentuālā sadalījuma noteikšanu starp interesējošajiem reǵioniem.

Gan aprakstīto (un izmantoto) metožu, gan piedāvātās modifikācijas efektivitātes pārbaudei darba ietvaros visas šīs metodes tika realizētas un pārbaudītas uz 6 aortas vārstuḷu fotogrāfisko attēlu piemēriem. Eksperimentālajā dạ̣ā segmentēšanas laiks tika samazināts aptuveni 300 reizes. Eksperimenti parādīja izvēelēto metožu efektivitāti praktiska uzdevuma risināšanā $(83,3$ \% gadījumos segmentācijas rezultātu neprecizitāte, neizmantojot manuālo korekciju, bija mazāk par $5 \%$ ). 
Александр Сысоев, Рихардс Старинский. Подход к быстрому извлечению статистических данных биомедицинских объектов Статистические данные биомедицинских объектов являются важной информацией для проведения медицинской диагностики и биомедицинских исследований. Таким образом, задача извлечения таких данных является актуальной с точки зрения медицинской практики (например, диагностика заболеваний и/или паталогоанатомические исследования сердечных клапанов). В настоящей работе рассматривается задача получения статистических данных из фотоизображений сердечных клапанов, а именно - аортальных клапанов (Valva aortae), извлеченнных в процессе хирургических операций.

Решение этой задачи разделено на три этапа. Первый этап - фотосъёмка имеющихся биомедицинских объектов с применением сквозного света. Второй этап заключается в сегментации фотоизображений, полученых на первом этапе. Для решения этой задачи в данной работе применены два известных метода распознавания образов: “сравнение с эталоном” и “«К» ближайших соседей”. В рамках работы предложена также модификация метода “«к» ближайших соседей”, позволяющая значительно ускорить сегментацию. На третьем этапе проводится подсчет размера интересующих сегментов с последующим расчётом процентного соотношения интересующих зон.Для проверки эффективности как описанных методов, так и предложеной в рамках работы модификации, эти методы были реализованы и проверены на примере фотографических изображений шести аортальных клапанов. В экспериментальной части время сегментации уменьшилось приблизительно в 300 раз. Результаты проведённых экспериментов показали эффективность выбраных методов в решении практической задачи (в 83,3\% случаев результаты сегментации без мануальной коррекции давали погрешность менее 5\%). 